\title{
MODEL OPTIMASI AGRO ECO-INDUSTRIAL PARK BERBASIS INDUSTRI TAHU DENGAN PENDEKATAN GOAL PROGRAMMING
}

\author{
Timotius Setiawan*1, Edy Suryadi², Boy M.P. Prawiranegara², Nurpilihan Bafdal'², Dwi R. \\ Kendarto $^{2}$ \\ ${ }^{1}$ Balai Pelatihan Kerja dan Transmigrasi Provinsi Jawa Tengah, \\ Jl. Raya Klampok No. 48 Km. 29 Banjarnegara, Indonesia 53474 \\ ${ }^{2}$ Magister Teknologi Agroindustri, Fakultas Teknologi Industri Pertanian, Universitas Padjadjaran, \\ Jl. Raya Bandung Sumedang KM 21, Hegarmanah, Jatinangor, Kab. Sumedang, Indonesia 45363
}

(Received: December 21, 2018/Accepted: January 6, 2020)

\begin{abstract}
Abstrak
Industri tahu di Kabupaten Sumedang menghadapi beberapa permasalahan terkait limbah, inefisiensi penggunaan air, dan ketergantungan terhadap bahan baku (kedelai) impor. Konsep Agro Eco-industrial Park (AEIP) berbasis industri tahu dapat menjadi alternatif solusi untuk memperbaiki kinerja industri tahu dan agroindustri terkait lainnya. Pengembangan AEIP perlu mempertimbangkan keseimbangan kapasitas untuk mengoptimalkan kinerja sistem. Penelitian ini bertujuan membangun suatu model optimasi AEIP berbasis industri tahu yang didukung agribisnis ternak sapi, usaha tani kedelai, produksi pupuk organik, dan unit biodigester. Penelitian dilakukan di sentra industri tahu Giriharja, Kabupaten Sumedang dengan menggunakan metode Goal Programming untuk memodelkan pertukaran material antar agroindustri. Model memasukkan lima variabel keputusan yaitu jumlah produksi tahu, jumlah produksi ternak sapi, jumlah produksi kedelai, jumlah produksi pupuk organik, dan jumlah produksi biogas. Kinerja model diukur dari sisa pertukaran material dan derajat daur ulang. Hasil penelitian menunjukkan bahwa model yang dibangun mampu memberikan solusi optimal berupa jumlah produksi untuk masing-masing agroindustri. Model juga menunjukkan kinerja yang lebih baik dibanding sistem yang sedang berjalan yang diindikasikan dengan penurunan sisa limbah dan peningkatan Recycle Rate.
\end{abstract}

Kata kunci: Agro Eco-Industrial Park; Goal Programming; Model Optimasi

\begin{abstract}
[Optimization Model of Agro Eco-industrial Park with Goal Programming Approach] The tofu industries in Sumedang Regency face several problems related to waste, water use inefficiencies, and dependence on imported raw materials (soybeans). The tofu industry-based Agro Eco-industrial Park (AEIP) concept can be an alternative solution to improve performance of tofu industries and other related agro-industries. The development of AEIP needs to consider the balance of capacity of each agro-industry to optimize performance of the system. This study aims to build an AEIP optimization model based on tofu industry supported by cattle agribusiness, soybean farming, organic fertilizer production, and biodigester units. The research was conducted in Giriharja tofu industrial cluster, Sumedang Regency by using Goal Programming method to model the material exchange between agroindustries. The model includes five decision variables which are the amount of tofu production, cattle production, soybeans production, organic fertilizer production, and biogas production. Performance of the model was indicated by total remain of material exchange and Recycle Rate. The results showed that the model is able to give optimal solutions of production amount for each agro-industry. The model also shows better performance than the current system as indicated by reduction of residual waste and increasing of Recycle Rate.
\end{abstract}

Keywords: Agro Eco-Industrial Park; Goal Programming; Optimization Model

*Penulis Korespondensi.

E-mail: timseti1985@yahoo.co.id 


\section{Pendahuluan}

Industri tahu merupakan salah satu agroindustri yang banyak ditemui di Kabupaten Sumedang. Pada 2017, jumlah industri tahu di Kabupaten Sumedang mencapai 282 unit usaha dengan jumlah produksi 12.483.204 kg/ bulan (Dinas Koperasi, 2018). Perkembangan industri tahu di Kabupaten Sumedang dan Jawa Barat tidak terlepas dari sosio-kultur masyarakat Sunda yang menjadikan tahu sebagai makanan favorit, menu sehari-hari, serta makanan khas yang diunggulkan dalam sektor pariwisata (Harahap, 2017).

Industri tahu menghasilkan limbah berupa limbah padat (ampas tahu) dan limbah cair. Selama ini limbah padat biasa dijual sebagai pakan ternak, sedangkan limbah cair biasa dibuang langsung ke sungai. Limbah cair industri tahu didominasi oleh kandungan bahan organik yang tinggi yang ditandai dengan kandungan Biologycal Oxygen Demand (BOD), Chemical Oxygen Demand (COD) dan Total Suspended Solid (TSS) yang tinggi serta $\mathrm{pH}$ yang rendah. Hal ini menyebabkan permasalahan pencemaran air dan bau tidak sedap pada sungai dan daerah sekitar agroindustri (Adack, 2013). Proses produksi tahu juga menggunakan air dalam jumlah besar. Kebutuhan air dan hasil limbah cair dari produksi tahu berturut-turut mencapai 3.700-4.500 liter dan 1.4004.300 liter per $100 \mathrm{~kg}$ kedelai yang diolah (Novita, Taruna, \& Wicaksono, 2016). Hal tersebut menunjukkan inefisiensi air dalam agroindustri tahu. Permasalahan lain yang dihadapi oleh industri tahu adalah ketersediaan bahan baku. Selama ini, produksi kedelai lokal belum mampu mencukupi kebutuhan kedelai untuk industri tahu sehingga kebutuhan kedelai dipenuhi dari kedelai impor.
Menurut (Djuwendah, Ma'mun, \& Hapsari, 2015), beberapa faktor yang menyebabkan rendahnya produksi kedelai di Kabupaten Sumedang adalah faktor teknis (penerapan teknologi produksi dan sarana irigasi), faktor sosial (keterbatasan pola tanam dan minat masyarakat), serta faktor ekonomis (keterbatasan lahan, modal dan daya saing kedelai lokal).

Konsep ekologi industri dapat menjadi alternatif pendekatan untuk permasalahan industri tahu. Sejak istilah ekologi industri diperkenalkan oleh Frosch dan Gallopoulos pada 1989, konsep ini telah banyak digunakan untuk melihat dan merekayasa sistem industri dari sudut pandang yang berbeda, komprehensif dan sistemik. Meskipun demikian, definisi mengenai ekologi industri menjadi beragam dan memunculkan banyak versi. Pengertian ekologi industri dimulai dari 'analogi biologis' yang dikemukakan oleh Frosch dan Gallopoulos, di mana sistem industri dianalogikan seperti ekosistem alam yang mendaur ulang sumber daya dengan sangat efektif. Pengertian lain dikemukakan oleh Robert White pada 1994 yang mendefinisikan ekologi industri sebagai "studi tentang aliran material dan energi dalam kegiatan industri (produksi) dan konsumsi, dampak dari aliran ini terhadap lingkungan, dan pengaruh faktor ekonomi, politik, kebijakan, dan sosial pada aliran, penggunaan, dan transformasi sumber daya" (Lifset \& Graedel, 2002). Dalam ekosistem industri, ada lima jenis anggota kunci yang memungkinkan terjadinya aliran material dan energi secara optimal: (1) produsen bahan baku utama; (2) pembangkit energi; (3) pengolah material; (4) pengolah sampah/limbah; dan (5) pengguna/ konsumen (Djajadiningrat \& Famiola, 2004).

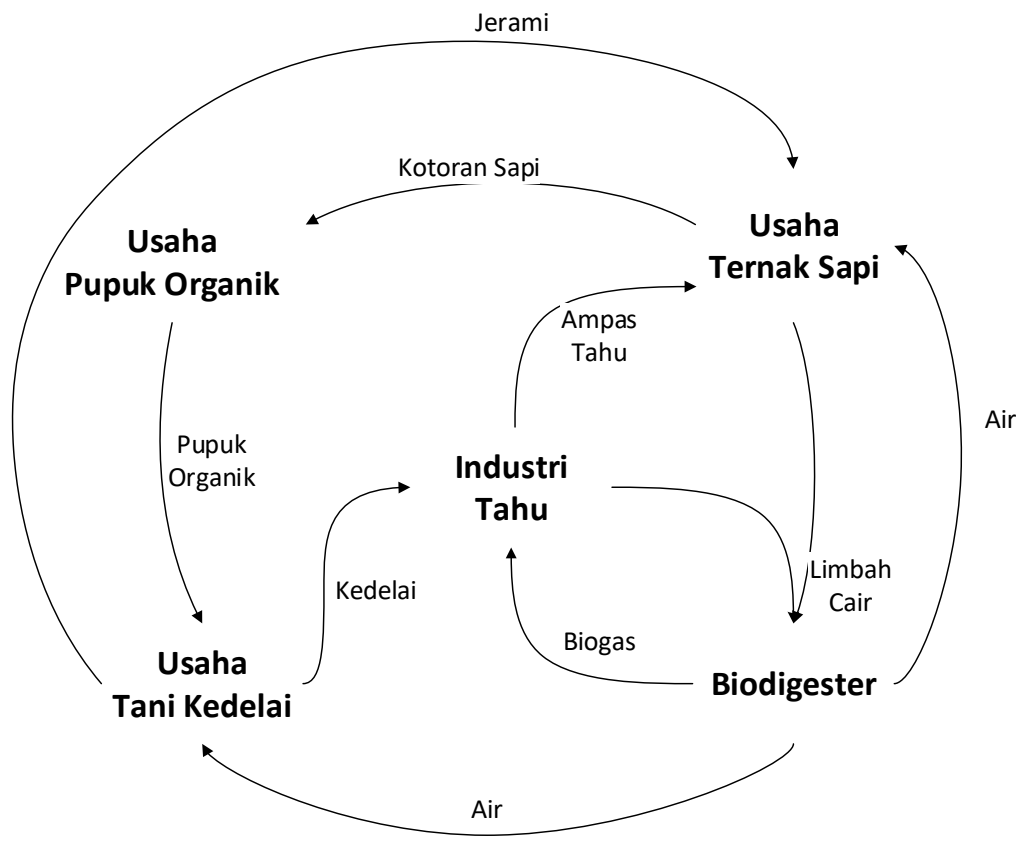

Gambar 1. Model Konseptual Agro Eco-industrial Park Berbasis Industri Tahu 
Salah satu bentuk penerapan konsep ekologi industri adalah kawasan agroindustri berwawasan lingkungan atau Eco-Industrial Park (EIP). EIP merupakan komunitas atau sekumpulan industri (baik manufaktur maupun jasa) yang berada di suatu kawasan bersama di mana seluruh industri berupaya meningkatkan kinerja lingkungan, ekonomi, dan sosial melalui kolaborasi dalam mengelola isu lingkungan dan sumber daya (Lowe, 2001). Agro Eco-Industrial Park (AEIP) merupakan bentuk penerapan konsep ekologi industri di mana beberapa agroindustri dalam satu kawasan saling berinteraksi untuk meningkatkan kinerja ekonomi, sosial dan lingkungan. Interaksi tersebut dilakukan dengan cara melakukan tukar menukar output (baik output produk maupun output non-produk), memanfaatkan limbah, membuat produk baru, menghemat penggunaan sumber daya, dan menerapkan rancangan ramah lingkungan pada sistem dan lingkungan produksi. AEIP dapat menjadi alternatif solusi untuk permasalahan limbah, inefisiensi penggunaan sumber daya air, ketersediaan bahan baku lokal pada industri tahu. Pada konsep tersebut, industri tahu menjadi industri basis yang memicu terjadinya pertukaran limbah dan material dengan agroindustri lainnya.

Pembentukan AEIP berbasis industri tahu perlu didukung dengan membangun agroindustri pendukung dan interaksi pertukaran material di antaranya. Agroindustri yang memiliki potensi untuk berintegrasi dan mendukung agroindustri tahu adalah usaha ternak sapi, budidaya kedelai, pengolahan pupuk organik, dan biodigester (Gambar 1). Usaha ternak sapi dapat memanfaatkan ampas tahu sebagai pakan tambahan. Budidaya kedelai dapat berperan sebagai penyedia bahan baku bagi agroindustri tahu sekaligus penyedia pakan hijauan bagi agroindustri ternak sapi. Usaha pengolahan pupuk organik dapat mengolah limbah kotoran ternak sapi dan mensuplai kebutuhan pupuk organik pada budidaya kedelai. Biodigester dapat mengolah limbah cair yang dihasilkan industri tahu maupun usaha ternak sapi.

Pengembangan AEIP berbasis agroindustri tahu juga perlu mempertimbangkan keseimbangan kapasitas produksi masing-masing agroindustri. Kapasitas produksi yang tidak berimbang pada setiap agroindustri dalam AEIP akan menyebabkan pertukaran material menjadi tidak optimal. Hal tersebut dapat menimbulkan sisa limbah agroindustri pada satu sisi dan kekurangan kebutuhan material agroindustri pada sisi yang lain. Hasil kinerja terbaik akan dapat diperoleh jika jumlah produksi masing-masing anggota cukup 'seimbang' untuk dapat menampung dan memanfaatkan output dari anggota yang lain. 'Keseimbangan' jumlah produksi dapat dicapai melalui optimasi jumlah produksi. Oleh karena itu diperlukan suatu 'model optimasi' yang dapat menggambarkan interaksi sekaligus memberikan nilai jumlah produksi yang optimal bagi agroindustri tahu, ternak sapi potong, budidaya kedelai, dan unit pembuatan pupuk organik dalam membentuk AEIP berbasis agroindustri tahu.

Kajian mengenai AEIP maupun optimasinya masih jarang dilakukan. Pojoh, dkk. (Pojoh, Syarief, Seminar, \& Sudarmasto, 2010) memodelkan pengembangan AEIP di Kota Bitung, Sulawesi Utara. Penelitian AEIP lainnya dilakukan oleh Santoso, dkk. (2014) yang mengkaji penerapan EIP di bidang agroindustri (Agro EIP) skala pedesaan pada sebuah perusahaan agrokompleks di Karangjati - Jawa Tengah yang terdiri dari industri tahu, peternakan sapi, industri pupuk organik dan biodigester. Penelitian tersebut menggunakan metode mathematical mass balance untuk mengetahui input dan output material dari setiap agroindustri. Penggunaan model optimasi Goal Programming dalam EIP pernah diterapkan oleh Tiu dan Cruz (2017) untuk memodelkan pertukaran air.

Penelitian ini bertujuan untuk membangun model optimasi yang menggambarkan interaksi pertukaran material antar agroindustri dalam AEIP berbasis industri tahu. Model tersebut diharapkan dapat digunakan untuk merencanakan kapasitas produksi untuk masing-masing agroindustri dalam AEIP berbasis industri tahu agar diperoleh kinerja sistem yang optimal.

\section{Bahan dan Metode}

Penelitian ini merupakan penelitian deskriptif, yaitu penelitian yang menggambarkan kondisi suatu objek (Natsir, 1999). Pendekatan yang digunakan adalah pendekatan kuantitatif di mana variabel-variabel dan hubungannya diukur dan diteliti sehingga menghasilkan data dalam bentuk angka (Creswell, 2014). Objek yang diteliti adalah konsep Agro Eco-industrial Park (AEIP) yang terdiri dari industri tahu, usaha ternak sapi, usaha tani kedelai, usaha pupuk organik dan unit biodigester serta pertukaran material, air dan energi di antaranya (Gambar 1). Lokasi yang dipilih adalah sentra industri tahu Giriharja yang berada di Desa Kebonjati, Kecamatan Sumedang Utara, Kabupaten Sumedang, di mana terdapat industri tahu, usaha ternak sapi, lahan pertanian, dan fasilitas Instalasi Pengolahan Air Limbah (IPAL) industri tahu yang juga berfungsi sebagai biodigester.

Pada sistem yang sedang berjalan saat ini (existing), baru terdapat tiga agroindustri yang berjalan, yaitu industri tahu, usaha ternak sapi, dan biodigester. Pertukaran limbah hanya terjadi antara industri tahu dengan usaha ternak sapi (dalam bentuk pertukaran ampas tahu) dan industri tahu dengan biodigester (dalam bentuk pertukaran limbah cair). Kondisi ini diperbaiki dalam model AEIP berbasis industri tahu dengan cara menambahkan usaha tani kedelai dan usaha pupuk organik, serta menciptakan interaksi pertukaran material, air dan energi antara anggota sebagaimana konsep AEIP berbasis industri tahu yang telah dijelaskan sebelumnya (Gambar 1). 
Metode yang digunakan untuk memodelkan sistem adalah metode Goal Programming, yaitu suatu model persoalan optimasi yang melibatkan beberapa variabel keputusan disertai fungsi pembatas untuk mencapai beberapa tujuan sekaligus (Tabucanon, 1988). Metode Goal Programming merupakan pengembangan dari metode Linear Programming, yaitu suatu metode optimasi matematis yang digunakan untuk menyelesaikan persoalan alokasi sumber-sumber yang terbatas untuk mendapatkan hasil terbaik (maksimum atau minimum) yang mungkin (Dimyati \& Dimyati, 2010). Terdapat tiga tipe fungsi pembatas dalam formulasi model optimasi Goal Programming: fungsi pembatas minimal, fungsi pembatas maksimal, dan fungsi pembatas pada nilai tertentu. Ketiga tipe fungsi pembatas tersebut dijelaskan dalam Tabel 1. (Fauziyah, 2016).

Tabel 1. Tipe-Tipe Fungsi dalam Formulasi Model Optimasi Goal Programming

\begin{tabular}{ccc}
\hline $\begin{array}{c}\text { Tipe } \\
\text { Fungsi } \\
\text { Pembatas }\end{array}$ & $\begin{array}{c}\text { Formulasi Fungsi } \\
\text { Matematika }\end{array}$ & $\begin{array}{c}\text { Variabel } \\
\text { Deviasi yang } \\
\text { Diminimumkan }\end{array}$ \\
\hline$f(x) \geq b_{1}$ & $f(x)+d_{1}^{-}-d_{1}^{+}=b_{1}$ & $d_{1}^{-}$ \\
$f(x) \leq b_{1}$ & $f(x)+d_{1}^{-}-d_{1}^{+}=b_{1}$ & $d_{1}^{+}$ \\
$f(x)=b_{1}$ & $f(x)+d_{1}^{-}-d_{1}^{+}=b_{1}$ & $d_{1}^{-}, d_{1}^{+}$ \\
\hline
\end{tabular}

Menurut Jones \& Tamiz (2010), ada empat filosofi yang mendasari Goal Programming, yaitu: kecukuppuasan (satisficing), pengoptimalan (optimising), pengurutan atau pemeringkatan (ordering/ ranking), dan penyeimbangan (balancing).

Goal Programming memiliki kekhasan dibanding Linear Programming, yaitu mengakomodasi beberapa tujuan sekaligus, baik maksimasi, minimasi, atau pemenuhan nilai target tertentu. Kekhasan model optimasi Goal Programming tersebut sesuai dengan tujuan pemodelan $A E I P$ berbasis agroindustri tahu, yaitu meminimasi sisa dari berbagai pertukaran material antar agroindustri.

Beberapa batasan dan asumsi perlu ditetapkan untuk memodelkan sistem AEIP berbasis agroindustri tahu. Pada penelitian ini, formulasi model terbatas pada:

1. lima jenis agroindustri, yaitu agroindustri tahu, usaha ternak sapi potong, usaha tani kedelai, usaha pupuk organik, dan unit biodigester;

2. lima variabel keputusan yang mewakili jumlah produksi dari masing-masing agroindustri;

3. pertukaran material berupa kedelai, ampas tahu, jerami, pupuk organik); pertukaran air berupa limbah cair tahu, limbah cair ternak sapi, limbah cair biodigester; dan pertukaran energi berupa biogas;

4. sumber daya yang digunakan berupa air, lahan (sawah irigasi dan non-irigasi) dan permintaan tahu;

5. kebutuhan air hanya pada usaha ternak sapi, usaha tani kedelai dan unit biodigester.
Asumsi-asumsi yang digunakan dalam pemodelan ini adalah:

1. variabel keputusan dan parameter yang diteliti bersifat linear;

2. kedelai yang dihasilkan dapat diterima dan digunakan untuk produksi tahu;

3. jerami kedelai dapat diterima dan digunakan sebagai pakan ternak sapi;

4. output ampas tahu dari produksi tahu yang menggunakan kedelai impor sama dengan output ampas tahu dari produksi tahu yang menggunakan kedelai lokal;

5. output kotoran sapi sama untuk setiap ekor sapi;

6. produksi biogas dari limbah cair tahu sama dengan produksi biogasi dari limbah cair ternak sapi;

7. nilai parameter tidak berubah dari waktu ke waktu atau sama dengan pada saat penelitian atau pengambilan data (tidak terpengaruh perubahan lingkungan atau musim);

8. seluruh tujuan (goal) memperoleh prioritas dan bobot yang sama.

Variabel keputusan dalam model ini adalah jumlah produksi masing-masing agroindustri dalam konsep AEIP yang disimbolkan $x_{i}$ di mana $(i=1,2,3,4,5)$ adalah jenis agroindustri. Model optimasi ini memasukkan parameter yang terkait dengan pertukaran material, air dan energi serta paramater yang terkait dengan ketersediaan sumber daya. Parameter-parameter tersebut adalah:

$m_{i j}=$ output material per unit produk agroindustri $i$ untuk digunakan pada agroindustri $j$;

$w_{i}=$ output limbah cair per unit produk agroindustri $i$;

$b_{j i}=$ kebutuhan material per unit produk agroindustri $j$ yang diperoleh dari agroindustri $i$;

$a_{j} \quad=$ kebutuhan air per unit produk agroindustri $j$;

$e_{j} \quad=$ kebutuhan energi per unit produk agroindustri $j$;

$f_{i}=$ kebutuhan lahan per unit produk agroindustri $i$;

$A_{i} \quad=$ ketersediaan air untuk agroindustri $i$;

$F_{i} \quad=$ ketersediaan lahan untuk agroindustri $i$;

$q_{i} \quad=$ permintaan produk agroindustri $i$.

Simbol $i$ dan $j$ digunakan untuk membedakan agroindustri yang berperan sebagai penghasil $(i)$ dengan agroindustri yang berperan sebagai pengguna $(j)$ dalam pertukaran material, air dan energi di mana $i=$ $1, \ldots, t ; j=1, \ldots, t ;$ dan $i \neq j$

Model dibangun dalam bentuk model Goal Programming tanpa prioritas (non-preemptive). Model Goal Programming berisi terdiri dari fungsi tujuan dan fungsi kendala. Fungsi tujuan berisi variabel penyimpangan positif $\left(d_{k}^{+}\right)$dan variabel penyimpangan negatif $\left(d_{k}^{+}\right)$yang diminimasi. Fungsi tujuan dituliskan sebagai berikut:

$$
\text { Minimasi } z=\sum_{k=1}^{t}\left(d_{k}^{+}+d_{k}^{-}\right)
$$

di mana,

$d_{k}^{+} \quad=$ variabel penyimpangan positif; 
$d_{k}^{-}=$variabel penyimpangan negatif;

$k=$ urutan fungsi kendala terkait tujuan; $k=1, \ldots, t$.

Fungsi kendala adalah fungsi yang menggambarkan kondisi-kondisi yang harus dipenuhi terkait dengan tujuan (goal) yang ingin dicapai maupun ketersediaan sumber daya. Fungsi kendala berisi variabel keputusan yang disertai dengan parameter terkait. Penelitian ini memasukkan enam jenis fungsi kendala, yaitu

fungsi kendala terkait minimasi sisa pertukaran material:

$$
m_{i j} x_{i}-b_{j i} x_{j}+d_{k}^{-}+d_{k}^{+}=0
$$

fungsi kendala terkait minimasi sisa pertukaran limbah cair:

$$
w_{i} x_{i}-a_{j} x_{j}+d_{k}^{-}+d_{k}^{+}=0
$$

fungsi kendala terkait minimasi sisa pertukaran energi:

$$
x_{i}-e_{j} x_{j}+d_{k}^{-}+d_{k}^{+}=0
$$

fungsi kendala terkait ketersediaan air:

$$
a_{i} x_{i} \leq A_{i}
$$

fungsi kendala terkait ketersediaan lahan:

$$
f_{i} x_{i} \leq F_{i}
$$

fungsi kendala terkait pemenuhan permintaan:

$$
x_{i}+d_{k}^{-}+d_{k}^{+}=q_{i}
$$

Penyelesaian persoalan optimasi pada Goal Programming dilakukan dengan algoritma simpleks. Pada penelitian ini, perhitungan simpleks dilakukan dengan bantuan software POM-QM for Windows 5 .

Kinerja model diukur berdasarkan nilai Recycle Rate (Derajat Daur Ulang). Recycle rate merupakan rasio jumlah limbah yang didaur ulang dibandingkan seluruh limbah yang dihasilkan (Leverenz, Tchobanoglous, dan Spencer, 2002). Recycle rate dapat menggambarkan tingkat optimalisasi seluruh proses metabolisme dalam AEIP (Djajadiningrat \& Famiola, 2004). Limbah padat memiliki satuan yang berbeda dengan limbah cair. Oleh karena itu perhitungan Recycle Rate dilakukan untuk masing-masing limbah padat dan limbah cair, dan kemudian dirata-rata untuk mendapatkan nilai Recycle rate komulatif yang dapat dituliskan sebagai berikut:

$$
\begin{aligned}
& R R_{\text {padat }}=\frac{L P U}{L P T} \times 100 \% \\
& R R_{\text {cair }}=\frac{L C U}{L C T} \times 100 \% \\
& R R_{\text {komulatif }}=\left(R R_{\text {padat }}+R R_{\text {cair }}\right) / 2
\end{aligned}
$$

di mana,

$R R_{\text {padat }}=$ Recycle Rate limbah padat $(\%)$;

$R R_{\text {cair }}=$ Recycle Rate limbah cair $(\%)$;

$R R_{\text {komulatif }}=$ Recycle Rate komulatif (\%);

$L P T=$ jumah limbah padat yang dihasilkan (kg/ hari);

$L P U=$ jumah limbah padat yang didaur ulang $(\mathrm{kg} / \mathrm{hari})$;

$L C T=$ jumah limbah cair yang dihasilkan (liter/ hari);
$L C U=$ jumah limbah cair yang didaur ulang (liter/ hari). Analisis Recycle Rate akan dilakukan pada tingkat agroindustri maupun tingkat sistem AEIP secara keseluruhan, baik pada sistem existing maupun pada model optimasi AEIP.

\section{Hasil dan Pembahasan}

Formulasi Model. Model optimasi didasarkan pada konsep $A E I P$ berbasis industri tahu yang terdiri dari industri tahu, usaha ternak sapi, usaha tani kedelai, usaha pupuk organik, dan unit biodigester. Interaksi pertukaran material, air dan energi serta kondisi ketersediaan sumber daya diterjemahkan ke dalam fungsi-fungsi yang terdiri dari jumlah kebutuhan, jumlah output atau ketersediaan dan penyimpangan yang mungkin terjadi. Gambar 2 mengilustrasikan aliran material, air dan energi pada AEIP berbasis industri tahu. Pertukaran kedelai. Industri tahu membutuhkan kedelai sebagai bahan baku untuk membuat tahu. Pertukaran kedelai dilakukan antara usaha tani kedelai dengan industri tahu. Produksi kedelai diharapkan sama dengan kebutuhan kedelai pada industri tahu. Pertukaran kedelai memungkinkan adanya penyimpangan positif (kelebihan produksi) atau penyimpangan negatif (kekurangan produksi) namun akan diminimasi dalam fungsi tujuan. Sehingga,

di mana,

$$
-b_{13} x_{1}+x_{3}+d_{1}^{-}-d_{1}^{+}=0
$$

$b_{13}=$ kebutuhan kedelai per baki tahu ( $\mathrm{kg} /$ baki);

$x_{1}=$ jumlah produksi tahu (baki/ hari);

$x_{3}=$ jumlah produksi kedelai ( $\mathrm{kg} /$ hari);

$d_{1}^{-}=$kekurangan jumlah produksi kedelai;

$d_{1}^{+}=$kelebihan jumlah produksi kedelai.

Pertukaran ampas tahu. Pertukaran ampas tahu dilakukan antara industri tahu dengan usaha ternak sapi. Jumlah ampas tahu yang dihasilkan diharapkan sama dengan kebutuhan ampas tahu di usaha ternak sapi. Pertukaran ampas tahu memungkinkan adanya penyimpangan positif (kelebihan output) atau penyimpangan negatif (kekurangan output) namun akan diminimasi dalam fungsi tujuan. Sehingga,

di mana,

$$
m_{12} x_{1}-b_{21} x_{2}+d_{2}^{-}-d_{2}^{+}=0
$$

$m_{12}=$ output ampas tahu per baki tahu (kg/ baki);

$x_{1}=$ jumlah produksi tahu (baki/ hari);

$b_{21}=$ kebutuhan ampas tahu per ekor sapi (kg/ ekor);

$x_{2}=$ jumlah ternak sapi (ekor).

$d_{2}^{-}=$kekurangan jumlah ampas tahu;

$d_{2}^{+}=$kelebihan jumlah ampas tahu; 


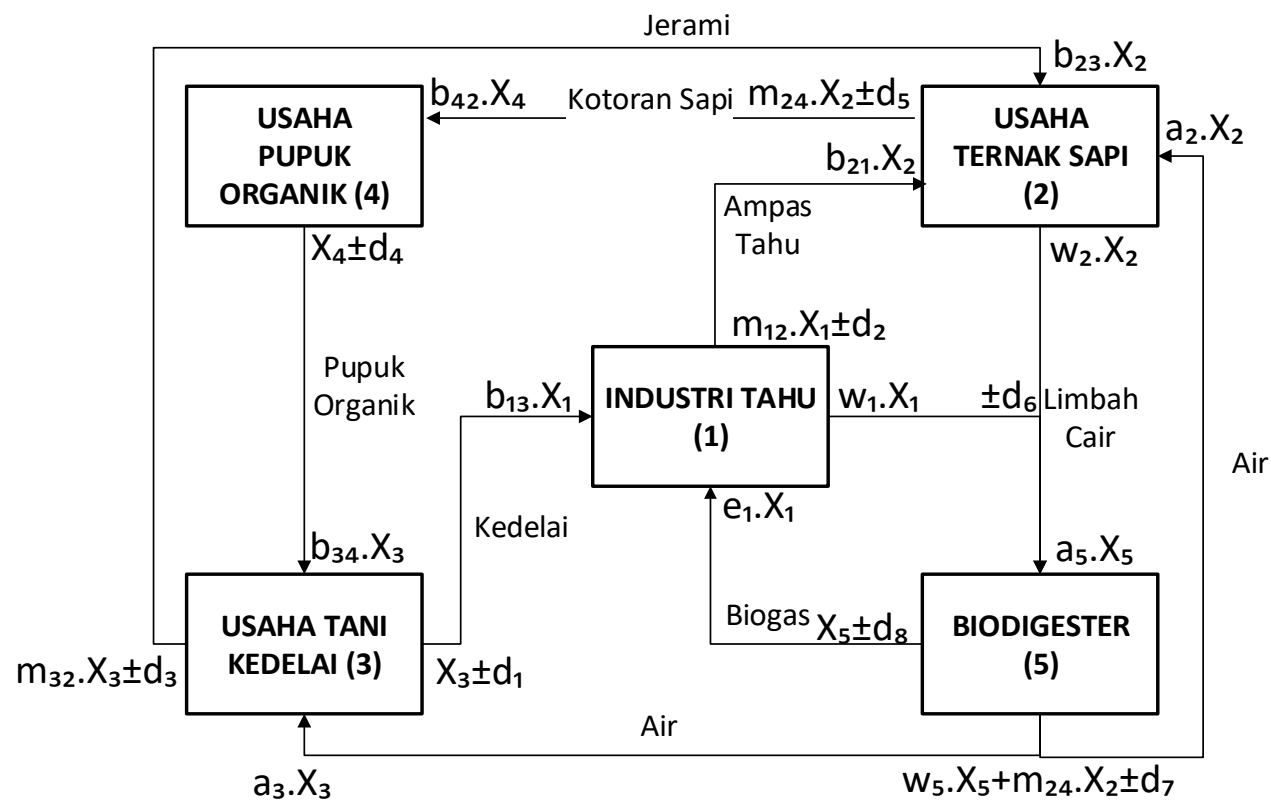

Gambar 2. Aliran Material, Air dan Energi pada Agro Eco-industrial Park Berbasis Industri Tahu

Pertukaran jerami. Pertukaran jerami dilakukan antara usaha tani kedelai dengan usaha ternak sapi. Jumlah jerami yang dihasilkan pada usaha tani kedelai diharapkan sama dengan jumlah kebutuhan jerami pada usaha ternak sapi. Pertukaran jerami memungkinkan adanya penyimpangan positif (kelebihan output) atau penyimpangan negatif (kekurangan output) namun akan diminimasi dalam fungsi tujuan. Sehingga,

di mana,

$$
-b_{23} x_{2}+m_{32} x_{3}+d_{3}^{-}-d_{3}^{+}=0
$$

$b_{23}=$ kebutuhan jerami ekor sapi ( $\mathrm{kg} /$ ekor);

$x_{2} \quad=$ jumlah ternak sapi (ekor);

$m_{32}=$ output jerami per $\mathrm{kg}$ kedelai $(\mathrm{kg} / \mathrm{kg})$;

$x_{3} \quad=$ jumlah produksi kedelai $(\mathrm{kg} / \mathrm{hari})$;

$d_{3}^{-}=$kekurangan jumlah jerami;

$d_{3}^{+}=$kelebihan jumlah jerami.

Pertukaran pupuk organik. Pertukaran pupuk organik dilakukan antara usaha pupuk organik dengan usaha tani kedelai. Jumlah pupuk organik yang dihasilkan pada usaha pupuk organik diharapkan sama dengan jumlah kebutuhan pupuk organik pada usaha tani kedelai. Pertukaran pupuk organik memungkinkan adanya penyimpangan positif (kelebihan output) atau penyimpangan negatif (kekurangan output) namun akan diminimasi dalam fungsi tujuan. Sehingga,

di mana,

$$
-b_{34} x_{3}+x_{4}+d_{4}^{-}-d_{4}^{+}=0
$$

$b_{34}=$ kebutuhan pupuk organik per kg kedelai $(\mathrm{kg} / \mathrm{kg})$;

$x_{3} \quad=$ jumlah produksi kedelai $(\mathrm{kg} / \mathrm{hari}) ;$

$x_{4} \quad=$ jumlah produksi pupuk organik (kg/ hari);

$d_{4}^{-} \quad=$ kekurangan jumlah pupuk organik;

$d_{4}^{+} \quad=$ kelebihan jumlah pupuk organik
Pertukaran kotoran sapi. Pertukaran kotoran sapi dilakukan antara usaha ternak sapi dengan usaha pupuk organik. Jumlah kotoran sapi yang dihasilkan pada usaha ternak sapi diharapkan sama dengan jumlah kebutuhan kotoran sapi pada usaha pupuk organik. Pertukaran kotoran sapi memungkinkan adanya penyimpangan positif (kelebihan output) atau penyimpangan negatif (kekurangan output) namun akan diminimasi dalam fungsi tujuan. Sehingga,

$$
m_{24} x_{2}-b_{42} x_{4}+d_{5}^{-}-d_{5}^{+}=0
$$

di mana,

$m_{24}=$ output kotoran sapi per ekor sapi (kg/ ekor);

$x_{2}=$ jumlah ternak sapi (ekor);

$b_{42}=$ kebutuhan kotoran sapi per kg pupuk organik $(\mathrm{kg} /$ $\mathrm{kg}$ );

$x_{4}=$ jumlah produksi pupuk organik $(\mathrm{kg} / \mathrm{hari})$;

$d_{5}^{-} \quad=$ kekurangan jumlah pupuk organik;

$d_{5}^{+}=$kelebihan jumlah pupuk organik.

Pertukaran limbah cair. Pertukaran limbah cair dilakukan antara industri tahu dan usaha ternak sapi dengan unit biodigester. Jumlah limbah cair yang dihasilkan oleh industri tahu dan usaha ternak sapi diharapkan sama dengan jumlah kebutuhan limbah cair oleh unit biodigester. Pertukaran limbah cair memungkinkan adanya penyimpangan positif (kelebihan output) atau penyimpangan negatif (kekurangan output) namun akan diminimasi dalam fungsi tujuan. Sehingga,

di mana,

$$
w_{1} x_{1}+w_{2} x_{2}-a_{5} x_{5}+d_{6}^{-}-d_{6}^{+}=0
$$

$w_{1}=$ output limbah cair per baki tahu (liter/ baki);

$x_{1}=$ jumlah produksi tahu (baki/ hari);

$a_{5}=$ kebutuhan limbah cair per $\mathrm{m}^{3}$ biogas $\left(\right.$ liter/ $\mathrm{m}^{3}$ ); 
$x_{5}=$ jumlah produksi biogas $\left(\mathrm{m}^{3} /\right.$ hari $)$;

$d_{6}^{-}=$kekurangan jumlah limbah cair;

$d_{6}^{+}=$kelebihan jumlah limbah cair.

Pertukaran air. Pertukaran air dilakukan antara usaha ternak sapi dan usaha tani kedelai dengan unit biodigester. Jumlah limbah cair terolah (treated water) yang dihasilkan oleh biodigester digabung dengan air irigasi diharapkan sama dengan jumlah kebutuhan air oleh usaha ternak sapi dan usaha tani kedelai. Pertukaran air memungkinkan adanya penyimpangan positif (kelebihan output) atau penyimpangan negatif (kekurangan output) namun akan diminimasi dalam fungsi tujuan. Kondisi tersebut menggabungkan pertukaran limbah cair pada persamana (3) dan ketersediaan (air irigasi) pada pertidaksamaan (5), sehingga,

$$
-a_{2} x_{2}-a_{3} x_{3}+w_{5} x_{5}+d_{7}^{-}-d_{7}^{+}=-A_{3}
$$

di mana,

$a_{2}=$ kebutuhan air kebersihan ternak (liter/ ekor);

$x_{2}=$ jumlah ternak sapi (ekor);

$a_{3}=$ kebutuhan air irigasi tanaman kedelai (liter/ kg);

$x_{3}=$ jumlah produksi kedelai ( $\mathrm{kg} /$ hari);

$w_{5}=$ output limbah cair per $\mathrm{m}^{3}$ biogas (liter/ $\left.\mathrm{m}^{3}\right)$;

$x_{5}=$ jumlah produksi biogas $\left(\mathrm{m}^{3} /\right.$ hari);

$d_{7}^{-}=$kekurangan jumlah air;

$d_{7}^{+} \quad=$ kelebihan jumlah air;

$A_{3} \quad=$ jumlah air irigasi yang tersedia (liter/ hari).
Pertukaran biogas. Selama ini, industri tahu menggunakan bahan bakar sekam padi, serbuk gergaji atau kayu bakar untuk proses perebusan bubur kedelai. Kebutuhan energi pada industri tahu dapat digantikan dengan biogas yang dihasilkan oleh unit biodigester. Produksi biogas oleh biodigester diharapkan cukup untuk memenuhi kebutuhan energi pada industri tahu. Pertukaran biogas antara unit biodigester dengan industri tahu memungkinkan adanya kelebihan produksi (penyimpangan positif) atau kekurangan produksi (penyimpangan negatif). Sehingga:

$$
-e_{1} x_{1}+x_{5}+d_{8}^{-}-d_{8}^{+}=0
$$

di mana,

$e_{1}=$ kebutuhan biogas per baki tahu ( $\left.\mathrm{m}^{3} / \mathrm{baki}\right)$;

$x_{1}=$ jumlah produksi tahu (baki/ hari);

$x_{5}=$ jumlah produksi biogas $\left(\mathrm{m}^{3} /\right.$ hari $)$;

$d_{8}^{-}=$kekurangan jumlah biogas;

$d_{8}^{+}=$kelebihan jumlah biogas .

Ketersediaan lahan budidaya. Produksi kedelai ditentukan oleh parameter kebutuhan lahan dan dibatasi oleh luas lahan yang tersedia untuk budidaya kedelai. Kondisi tersebut dituliskan dalam fungsi:

di mana,

$$
f_{3} x_{3} \leq F_{3}
$$

$f_{3}=$ kebutuhan lahan per $\mathrm{kg}$ kedelai $\left(\mathrm{m}^{2} / \mathrm{kg}\right)$;

$x_{3}=$ jumlah produksi kedelai ( $\mathrm{kg} /$ hari);

\begin{tabular}{|c|c|c|}
\hline Parameter & Simbol & Nilai \\
\hline Output ampas tahu (kg/ baki) & $m_{12}$ & 3,04 \\
\hline Output kotoran sapi (kg/ ekor) & $m_{24}$ & 25 \\
\hline Output jerami per $\mathrm{kg}$ kedelai $(\mathrm{kg} / \mathrm{kg})$ & $m_{32}$ & 2,27 \\
\hline Output limbah cair tahu (liter/baki) & $w_{1}$ & 51,92 \\
\hline Output limbah cair sapi (liter/ekor) & $w_{2}$ & 50 \\
\hline Output limbah cair biodigester (liter/ $\mathrm{m}^{3}$ ) & $w_{5}$ & 71,43 \\
\hline Kebutuhan kedelai (kg/baki) & $b_{13}$ & 1,65 \\
\hline Kebutuhan ampas tahu (kg/ekor) & $b_{21}$ & 5 \\
\hline Kebutuhan jerami (kg/ekor/hari) & $b_{23}$ & 10,1 \\
\hline Kebutuhan pupuk organik $(\mathrm{kg} / \mathrm{kg})$ & $b_{34}$ & 1 \\
\hline Kebutuhan kotoran sapi $(\mathrm{kg} / \mathrm{kg})$ & $b_{42}$ & 1,38 \\
\hline Kebutuhan air kebersihan (liter/ekor) & $a_{2}$ & 40 \\
\hline Kebutuhan air tanaman (liter $/ \mathrm{kg}$ ) & $a_{3}$ & 745,5 \\
\hline Kebutuhan limbah cair (liter/m ${ }^{3}$ ) & $a_{5}$ & 71,43 \\
\hline Kebutuhan biogas ( $\left.\mathrm{m}^{3} / \mathrm{baki}\right)$ & $e_{1}$ & 0,6 \\
\hline Kebutuhan lahan $\left(\mathrm{m}^{2} / \mathrm{kg}\right)$ & $f_{3}$ & 5 \\
\hline Ketersediaan air irigasi (liter/hari) & $A_{3}$ & 422.253 \\
\hline Ketersediaan lahan budidaya ( $\mathrm{m}^{2} /$ hari) & $F_{3}$ & 6.653 \\
\hline Permintaan tahu (baki/hari) & $q_{1}$ & 1.260 \\
\hline
\end{tabular}

$F_{3} \quad=$ ketersediaan lahan budidaya kedelai $\left(\mathrm{m}^{2} /\right.$ hari $)$.

Tabel 2. Nilai Parameter Model Optimasi AEIP

Pemenuhan permintaan tahu. Pengusaha tahu memutuskan untuk memenuhi permintaan tahu tanpa adanya kekurangan produksi $\left(\mathrm{d}^{-}\right)$maupun kelebihan produksi $\left(\mathrm{d}^{+}\right)$sehingga produksi tahu harus sama dengan jumlah permintaan. Kondisi tersebut dituliskan dalam fungsi:

di mana,

$$
x_{1}=q_{1}
$$

$x_{1}=$ jumlah produksi tahu (baki/ hari); 
$q_{1}=$ jumlah permintaan tahu (baki/ hari).

Nilai Parameter: Nilai parameter dalam model optimasi AEIP berbasis industri tahu dihitung berdasarkan data dari lokasi penerapan model. Pada penelitian ini, nilai parameter diperoleh berdasarkan data di sentra industri tahu Giriharja Kabupaten Sumedang sebagaimana dicantumkan dalam Tabel 2.

Analisis Variabel Keputusan. Berdasarkan perhitungan simpleks diperoleh solusi optimal berupa jumlah produksi untuk masing-masing agroindustri dalam AEIP berbasis industri tahu di sentra industri tahu Giriharja sebagaimana dicantumkan dalam Tabel 3.

Tabel 3. Perbandingan Jumlah Produksi pada Sistem Existing dengan Jumlah Produksi Optimal dari Model Optimasi AEIP

\begin{tabular}{lccc}
\hline \multirow{2}{*}{ Agroindustri } & \multicolumn{3}{c}{ Jumlah Produksi } \\
\cline { 2 - 4 } & Existing & Optimasi & Satuan \\
\hline Industri Tahu & 1.260 & 1.260 & baki/hari \\
Ternak Sapi & 40 & 147,47 & ekor/periode \\
Kedelai & 0 & 656,13 & $\mathrm{~kg} / \mathrm{hari}$ \\
Pupuk & 0 & $1.496,05$ & $\mathrm{~kg} / \mathrm{hari}$ \\
Organik & & & \\
Biodigester & 336 & $1.019,08$ & $\mathrm{~m}^{3} / \mathrm{hari}$ \\
\hline
\end{tabular}

Sistem existing terdiri dari tiga agroindustri, yaitu industri tahu, usaha ternak sapi dan biodigester. Model optimasi AEIP menambahkan dua agroindustri pendukung, yaitu usaha tani kedelai dan usaha pupuk organik. Jumlah produksi pada usaha ternak sapi dan biodigester pada model optimasi AEIP lebih tinggi dibanding sistem existing. Penambahan agroindustri pendukung dan peningkatan jumlah produksi pada model optimasi AEIP merupakan perwujudan dari optimalisasi pemanfaatan limbah dan pemenuhan kebutuhan material dari dalam sistem. Usaha tani kedelai dibangun untuk memasok kebutuhan kedelai pada industri tahu, sedangkan usaha pupuk organik dibangun untuk mengolah limbah kotoran yang belum dimanfaatkan pada sistem existing. Peningkatan jumlah produksi ternak sapi berdampak pada peningkatan pemanfaatan ampas tahu dan jerami kedelai. Peningkatan produksi biogas berdampak pada peningkatan pemanfaatan limbah cair industri tahu dan limbah cair ternak sapi.

Analisis Penyimpangan. Tujuan yang ditetapkan dalam model optimasi $A E I P$ adalah minimasi sisa pertukaran material. Model optimasi AEIP menghasilkan jumlah produksi yang paling 'seimbang' dengan sisa pertukaran paling minimal yang mungkin bisa dicapai. Sisa pertukaran material diwakili dengan variabel penyimpangan positif $\left(\mathrm{d}^{+}\right)$dan variabel penyimpangan negatif $\left(\mathrm{d}^{-}\right)$. Tabel 4 menunjukkan nilai penyimpangan yang dicapai dari model optimasi $A E I P$.

Pada pertukaran kedelai terdapat kekurangan produksi sejumlah 422,87 yang ditunjukkan pada nilai variabel $\mathrm{d}^{-}$. Kekurangan ini harus dipenuhi dari luar sistem dengan cara mendatangkan kedelai dari luar. Pada pertukaran ampas tahu, pupuk organik, air, dan biogas terdapat kelebihan produksi masing-masing sejumlah 3093,06 kg/hari, 839,91 kg/hari, 0,03 liter/hari dan $263,08 \mathrm{~m}^{3} /$ hari. Kelebihan produksi ampas tahu, pupuk organik, air dan biogas tidak akan berdampak buruk pada lingkungan karena ampas tahu, pupuk organik, air dan biogas memiliki manfaat dan nilai ekonomi sehingga dapat digunakan untuk untuk memenuhi permintaan di luar sistem.

Tabel 4. Nilai Penyimpangan Positif $(\mathrm{d}+)$ dan Penyimpangan Negatif (d-) dari Model Optimasi AEIP

\begin{tabular}{lcc}
\hline \multicolumn{1}{c}{ Kendala } & $\mathbf{d}^{+}$ & $\mathbf{d}^{-}$ \\
\hline Pertukaran Kedelai & 0 & 1422,87 \\
Pertukaran Jerami & 0 & 0 \\
Pertukaran Ampas Tahu & $3.093,06$ & 0 \\
Pertukaran Pupuk Organik & 839,91 & 0 \\
Pertukaran Kotoran Sapi & 0 & 0 \\
Pertukaran Limbah Cair & 0 & 0 \\
Pertukaran Air & 0,03 & 0 \\
Pertukaran Biogas & 263,08 & 0 \\
\hline
\end{tabular}

Analisis Recycle Rate. Recycle Rate dihitung pada tingkat agroindustri maupun sistem AEIP keseluruhan. Hasil perhitungan Recycle Rate pada sistem existing dan model optimasi AEIP disajikan dalam Tabel 5.

Tabel 5. Perbandingan Recycle Rate antara Sistem Existing dengan Model Optimasi AEIP

\begin{tabular}{lcc}
\hline \multirow{2}{*}{\multicolumn{1}{c}{ Agroindustri }} & \multicolumn{2}{c}{ Recycle Rate } \\
\cline { 2 - 3 } & Existing & Optimasi \\
\hline Industri Tahu & $21 \%$ & $59,6 \%$ \\
Usaha Ternak Sapi & $0 \%$ & $100 \%$ \\
Usaha Tani Kedelai & - & $100 \%$ \\
Usaha Pupuk Organik & - & - \\
Biodigester & $0 \%$ & $100 \%$ \\
Sistem Keseluruhan & $\mathbf{1 5 , 4 \%}$ & $\mathbf{7 9 , 1 \%}$ \\
\hline
\end{tabular}

Pada sistem existing, hanya terdapat industri tahu, usaha ternak sapi dan biodigester. Nilai Recycle Rate menunjukkan bahwa pada sistem existing, hanya $21 \%$ limbah industri tahu yang didaur ulang dan $0 \%$ limbah ternak sapi dan biodigester yang didaur ulang. Hal tersebut bisa dipahami karena hanya sebagian limbah padat dan limbah cair tahu yang dimanfaatkan, sedangkan limbah kotoran sapi, limbah cair ternak sapi, dan limbah cair biodigester belum dimanfaatkan sama sekali.

Pada model optimasi AEIP, terdapat empat agroindustri menghasilkan limbah yaitu industri tahu, usaha ternak sapi, usaha tani kedelai, dan biodigester, sedangkan usaha pupuk organik tidak menghasilkan limbah. Nilai Recycle Rate menunjukkan bahwa limbah ternak sapi, limbah usaha tani kedelai dan limbah 
biodigester telah didaur ulang seluruhnya. Di sisi lain sebanyak 59,6\% limbah industri tahu telah didaur ulang.

Secara keseluruhan, sistem existing mencapai Recycle Rate sebesar 15,4\% yang diperoleh dari pemanfaatan sebagian ampas tahu sebagai pakan ternak dan sebagian limbah cair tahu untuk biogas. Model optimasi AEIP mampu meningkatkan Recycle Rate hingga $79,1 \%$ yang dicapai melalui pemanfaatan sebagian ampas tahu dan seluruh limbah cair tahu, limbah cair ternak sapi, limbah cair biodigester, limbah kotoran sapi, dan limbah jerami kedelai.

\section{Kesimpulan}

Metode non-preemptive Goal Programming dapat digunakan untuk membangun model optimasi Agro Ecoindustrial Park (AEIP) berbasis industri tahu. Model optimasi $A E I P$ berbasis industri tahu merepresentasikan pertukaran material, air, dan energi dan penggunaan sumber daya di antara industri tahu, usaha ternak sapi, usaha tani kedelai, usaha pupuk organik dan unit biodigester. Model menghasilkan output solusi optimal berupa jumlah produksi masing-masing agroindustri yang berguna dalam perencanaan kapasitas agroindustri dalam rangka pengembangan AEIP. Kinerja model optimasi $A E I P$ lebih baik dibanding sistem existing yang ditunjukkan dengan penurunan sisa limbah (hingga 0 liter limbah cair/hari) dan peningkatan Recycle Rate dari $15,4 \%$ pada sistem existing menjadi $79,1 \%$ pada model optimasi.

\section{Ucapan Terima Kasih}

Terima kasih disampaikan kepada seluruh narasumber: Kelompok Pengusaha Tahu Giriharja Sumedang, Kelompok Tani Raharja, Balai Penyuluh Pertanian (BPP) Kec. Sumedang Utara, Balai Pengamatan Antariksa dan Atmosfer (BPAA) Sumedang, dan Loka Penelitian Teknologi Bersih - Lembaga Ilmu Pengetahuan Indonesia.

\section{Daftar Pustaka}

Adack, J. (2013). Lex Administratum, Vol.I/No.3/JulSept/2013. Lex Administratum, I(3), 78-87.

Creswell, J. W. (2014). Research Design: Qualitative, Quantitative and Mixed Methods Approaches, 4 Edition. London: Sage.

Dimyati, T. \& Dimyati, A. (2010). Model-model Pengambilan Keputusan. Bandung: Sinar Baru Aglesindo.

Dinas Koperasi, UKM, Perindustrian dan Perdagangan Kabupaten Sumedang. (2018). Data Industri di Kabupaten Sumedang. Kabupaten Sumedang, Jawa Barat, Indonesia.

Djajadiningrat, S. T., \& Famiola, M. (2004). Kawasan Industri Berawawasan Lingkungan (Eco-Industrial Park): Fenomena Baru dalam Membangun
Industri dan Kawasannya Demi Masa Depan Berkelanjutan. Bandung: Rekayasa Sains.

Djuwendah, E., Ma'mun, D., \& Hapsari, H. (2015). Kajian Potensi Kedelai Lokal sebagai Bahan Baku Industri Tahu Sumedang. Prosiding Seminar Nasional, Agribisnis Kedelai: Antara Swasembada dan Kesejahteraan Petani, 322-330.

Fauziyah. (2016). Penerapan Metode Goal Programming untuk Mengoptimalkan Beberapa Tujuan pada Perusahaan dengan Kendala Jam kerja, Permintaan dan Bahan Baku. Jurnal Matematika Mantik Vol. 02 (1) Oktober 2016.

Harahap, J. (2017). Tahu Sumedang sebagai Makanan Orang Sunda yang Sehat dan Bergizi: Sebuah Studi Ilmu Sosial untuk Kesehatan, 10(1), 117128 .

Jones, D., Tamiz, M. (2010). Practical Goal Programming (International Series in Operations Research \& Management Science). New York: Springer.

Leverenz, H., Tchobanoglous, G., Spencer, D.B. (2002). Recycling. In G. Tchobanoglous \& F. Kreith. (Ed) Handbook of Solid Waste Management (pp.8.18.77). 2nd Ed. McGraw-Hill.

Lifset, R., \& Graedel, T. E. (2002). No Title. In R. U. Ayres \& L. W. Ayres (Eds.), A Handbook of Industrial Ecology (pp. 3-15). Northampton Massachusetts: Edward Elgar Publishing Inc. Retrieved from http://pustaka.unp.ac.id/file/abstrak_kki/EBOOKS /A Handbook of Industrial Ecology.pdf

Lowe, E. A. (2001). Eco-industrial Park Handbook for Asian Developing Countries. Oakland: Indigo Development. Retrieved from www.indigodev.com

Natsir, M. (1999). Metodologi Penelitian. Jakarta: Galia Indonesia.

Novita, E., Taruna, I., \& Wicaksono, T. F. (2016). Prosiding Seminar Nasional Apta, Jember 26-27 Oktober 2016, 376-381.

Pojoh, B., Syarief, R., Seminar, K., \& Sudarmasto. (2010). Model Pengembangan Agroecoindustrial Park Kota Bitung. Jurnal Riset Industri2, IV, 4352. Melalui http://webcache.googleusercontent. com/search?q=cwww.kemenperin.go.id/download /4741/Model-Pengembangan-Agro-EcoIndustrial-Park-di-Kota-Bitung-ProvinsiSulawesi-Utara $+\& \mathrm{~cd}=2 \& \mathrm{hl}=\mathrm{id} \& \mathrm{ct}=\mathrm{clnk} \& \mathrm{gl}=\mathrm{id}$

Santoso, H., Susanty, A., dan Putriasih, J. (2014). Rekayasa Ekologi Industri dalam Mendukung Pembangunan Agro Eco-Industrial Park Skala Pedesaan. J@TI Undip Vol. IX, No. 2, Mei 2014.

Tabucanon, M. T. (1988). Multiple Criteria Decision Making in Industry. New York: Elsevier Science Publishing Company, Inc. 
Tiu, Bryan T. C. \& Cruz, D. E. (2017). An MILP Model for Optimizing Water Exchanges in Eco Industrial Parks Considering Water Quality. Resources, Conservation and Recycling Vol. 119 April 2017. Melalui

https://doi.org/10.1016/j.resconrec.2016.06.005 [03/01/2019] 